\title{
Prioriteringer i helsetjenesten
}

\section{Sentrale prioriteringsprinsipper må spesifiseres for at de skal kunne} være til hjelp.

Begrensede ressurser tvinger oss til å prioritere $\mathrm{i}$ helsetjenesten.

- Vi tar utgangspunkt i to overordnede prioriteringsprinsipper: prioritet til tjenestene som gir størst helsegevinst og prioritet til tjenestene som hjelper de dårligst stilte. Skal disse prinsippene være til hjelp i faktiske prioriteringer, må de spesifiseres og veies mot hverandre, sier Trygve Ottersen.

I sin avhandling har han undersøkt hvilke aspekter ved helsekvalitet som bør vektlegges, hvordan «de dårligst stilte» bør spesifiseres og hvordan de to overordnede prinsippene bør veies mot hverandre.

- Vi foreslår at «de dårligst stilte» er de med lavest forventet kvalitetsjustert levealder eller færrest kvalitetsjusterte leveår (QALY) i løpet av livet og analyserer grunnlaget for dette. Denne definisjonen kan innebære høyere prioritet til tilstander som gir lav livskvalitet eller som rammer unge, sier Ottersen. - Videre undersøkte vi empirisk hvordan to ulike grupper ønsket å balansere de to prinsippene. Både beslutningstakere i Tanzania og norske studenter ga støtte til begge prinsippene. Hos studentene kunne vi tallfeste avveiningen. En QALY ble, for eksempel, vurdert som 3,3 ganger mer verdifull når målgruppen hadde en forventet kvalitetsjustert levealder på ti år sammenliknet med 70 år, sier Ottersen.

- Å begrense potensielt nyttig behandling er noe av det vanskeligste vi kan gjøre. Jeg håper derfor min avhandling kan bidra til bedre verktøy for prioritering i helsetjenesten, avslutter han.

\section{Anne Forus}

anneforus@hotmail.com

Tidsskriftet

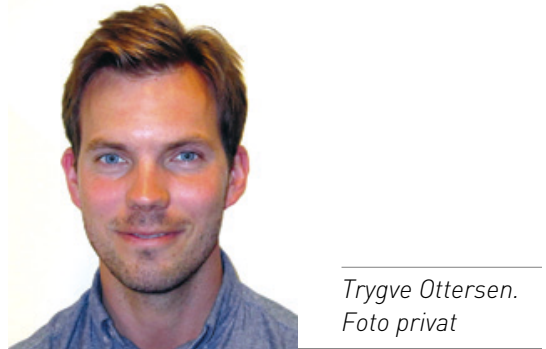

\section{Disputas}

Trygve Ottersen disputerte for ph.d.-graden ved Universitetet i Bergen 26.4. 2013. Tittelen på avhandlingen er Greater benefits and the worse off: specifying and balancing prioritysetting principles in health.

\section{Hvor kommer cystene i hodet fra?}

\section{Araknoidale cyster er godartede, væskefylte hulrom i hjernen som ses hos opptil 1,1\% av befolkningen. Men hvor kommer de fra? Forskere i Bergen har kommet ett steg nærmere svaret.}

Araknoidale cyster oppstår ved at den mellomste av de tre hjernehinnene, spindelvevshinnen (arachnoidea), deler seg i to lag med væske mellom seg. Dette forårsaker trykk mot hjernen og kan gi diffuse plager som slapphet, hodepine og lese- og skrivevansker. Hvorfor cystene oppstår og på hvilken måte de fylles, har ingen foreløpig klart å forklare.

Lege Magnus Berle har tatt prøver av væsken i cystene og sammenliknet med cerebrospinalvæske fra de samme pasientene.

- Vi ville finne ut om det var noen forskjell mellom disse væskene og hva som gjør at cystene fyller seg opp, sier Berle.

Det er bare et tynt lag mellom cysten og cerebrospinalvæsken. Hittil har det versert tre teorier om hvordan cystene fylles: via pumpemekanisme/aktiv transport, via klaffe- ventil eller via salttrykk/osmose. Berle og kollegene brukte en relativt ny metode, proteomikk, for å analysere væskene. De fant at væsken $\mathrm{i}$ cystene liknet veldig på spinalvæske. Den er imidlertid ikke helt lik.

- Vi fant mindre proteiner i cystevæsken enn i spinalvæsken, noe som ikke stemmer med salttrykk eller klaffeventil som mekanisme. Vi tror heller at cysten oppstår som følge av aktiv transport over hinnen gjennom en pumpemekanisme. Proteininnholdet tilsier at denne transporten skjer fra spinalvæsken og ikke fra blodbanen. Vi er altså et lite steg nærmere å forstå hvor cystene $\mathrm{i}$ hodet kommer fra, sier Berle.

\section{Eline Feiring}

eline.feiring@legeforeningen.no

Tidsskriftet

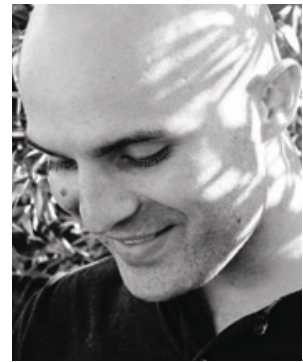

Magnus Berle. Foto Stuart Mclntyre

Disputas

Magnus Berle disputerte for ph.d.-graden 3.5. 2013 ved Universitetet i Bergen, med avhandlingen Characterization of arachnoid cysts using clinical chemistry, qualitative and quantitative proteomics. 